\title{
Varro, the Name-Givers, and the Lawgivers: The Case of the Consuls
}

\author{
Valentina Arena \\ Professor of Ancient History, University College London, London, UK \\ v.arena@ucl.ac.uk
}

\begin{abstract}
This essay aims at identifying a tradition of lawgivers in the political culture of the late Republic. It focuses on the antiquarian tradition of the second half of the first century в , which, it argues, should be considered part of the wider quest for legal normativism that takes place towards the end of the Republic. By reconstructing the intellectual debates on the nature of the consulship, which at the time was carried out through the means of etymological research, this essay shows that, when set within its proper philosophical framework, ancient etymological studies acted as a search for philosophical truth and, in the case of Varro, identify the early kings as the first Roman lawgivers. In turn, the language of political institutions and its etymologies, conceived along philosophical lines, could become a weapon in the constitutional battles of the late Republic.
\end{abstract}

\section{Keywords}

consul - etymology - kings - Cincius - Varro

\section{$1 \quad$ Introduction}

As is well known, contrary to the Greek tradition, the Roman Republican system did not recognise a single Lawgiver. While Sparta could boast Lycurgus as the founder of its constitution, Athens Solon, and Crete Minos, Roman tradition did not assign the beginning of its public laws and institutions to a single individual, but rather to the contributions of many men throughout several 
centuries. This view is famously enshrined in a fragment of Cato the Elder, preserved in Cicero's de re publica, which reads as follows:

the constitution of our city (nostrae ciuitatis statum) is superior to other cities for this reason, that in their case there had been usually individuals each of whom set up his commonwealth with his own laws and institutions (suam quisque rem publicam constituisset legibus atque institutis suis), as Minos did for the Cretans, Lycurgus for the Spartans, and for the Athenians, whose constitution underwent frequent changes, first Theseus, then Draco, then Solon, then Cleisthenes, then many others, and finally, when it lay bloodless and prostrate, that learned man Demetrius of Phalerum revived it; our commonwealth, on the other hand, was established by the intelligence not of one man, but of many, not in one man's lifetime, but over several centuries and ages (nostra autem res publica non unius esset ingenio, sed multorum, nec una hominis vita, sed aliquot constituta saeculis et aetatibus). For, there had never existed human intelligence so great that there might have been someone at some time whom nothing would escape, nor could the combined intelligence of all great minds at a single moment of time make sufficient provision to take account of everything, without experience of affairs over a long period of time. Fr. 131 FRHist (= Cic. Rep. $2.1-3)^{1}$

Most interestingly, in a passage that many scholars consider dependent on Cato, Polybius propounded a not dissimilar view in his discussion of the Roman constitution in Book $6 .^{2}$ Applauding the main features of the Spartan politeia, Polybius attributes them to Lycurgus and draws a stark contrast with Rome, whose status civitatis was indeed the outcome of trials and errors: 'Lycurgus

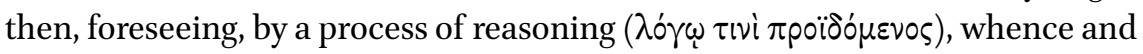
how events naturally happen, constructed his constitution untaught by adversity, but the Romans while they have arrived at the same final result as regards their form of government, have not reached it by any process of reasoning,

1 This passage comes probably from Cato's Origines. Cf. Cic. Rep. 2.23-4 on the uninterrupted sequence of additions to the original form of commonwealth.

2 C. Nicolet, 'Polybe et les institutions romaines', in E. Gabba (ed.), Polybe, Entretiens sur l'Antiquité Classique (Vandoeuvres-Genève: Foundation Hardt, 1974), pp. 209-58, esp. pp. 243-55 who argues for an 'ideological' dependence of Polybius on Cato (which Momigliano criticizes in his commentary on Nicolet's paper, p. 261). For further bibliography see V. Arena, Libertas and the Practice of Politics in the Late Roman Republic (Cambridge: Cambridge University Press, 2012), pp. 85-7. 


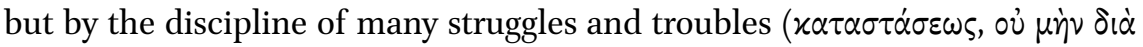

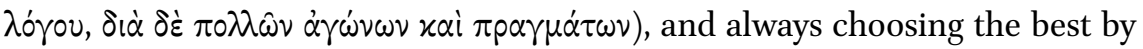
the light of the experience gained in disaster have thus reached the same result as Lycurgus and the best of all existing constitutions' (Polyb. 6.10.12-4.).

Thus, it was not the logos of a single Lawgiver, but rather the ability to choose the best in troubles and disasters on the part of many men throughout several generations that established Rome's status civitatis.

The absence in Roman tradition of a unifying single moment in which one individual acted as lawgiver yielded as a result not only the lack of a written law-code, but also the clear perception that the working of the commonwealth was based on rules and regulations, which were subject to constant modification, re-interpretation, and ultimately contestation.

Within this framework, which was part of Roman political consciousness, in the late Republic it is possible to observe, as Emilio Gabba pointed out some time ago, a tendency towards a unification process of public laws, something akin to a quest for normativism. ${ }^{3}$ This process had at least three distinctive and salient moments: first, from the second half of the second century BC, Rome's writing down the constitutions of its own colonial foundations and modifying the constitutional structures of the communities under its control; second, the constitutional reforms of the dictators Sulla and Caesar. In 81 вс the first became dictator legibus scribundis et rei publicae constituendae or, as Appian put it, 'for setting the politeia in order;' while in 46 вс Caesar took up the dictatorship with the aim 'of setting public affairs in order'. ${ }^{4}$ Third, most likely in the second half of the first century вС, the composition of the ius Papirianum, which was said to include the archaic laws of Romulus and Numa, probably first collected by the pontifex maximus Gaius Papirius, and commented on by Granius Flaccus at the time of Caesar. ${ }^{5}$ Although we do not know the exact nature of these laws and their historicity is highly contested, their compilation responded to the contemporary late Republican need for an organic complex of constitutional and religious norms to be attributed to a remote, kingly, past. ${ }^{6}$

3 E. Gabba, 'Tendenze all'unificazione normativa nel diritto pubblico tardo-repubblicano', in E. Gabba (ed.), Italia Romana (Como: Edizioni New Press, 1994), pp. 45-5o = M. Sargenti and G. Luraschi, La certezza del diritto nell'esperienza giuridica romana: Atti del Convegno, Pavia, 26-27 aprile 1985 (Padova: CEDAM, 1987), pp. 169-77.

4 App. B. Civ. 1.99.462. C. Ando, 'The origins and import of republican constitutionalism', Cardozo Law Review 34 (2013), pp. 917-35.

5 Dig. 1.2.2.2. and 36; on Gaius Papirius Dion. Hal. 3.36.4; Liv. 1.32.2 and 6.1.10; on Granius Flaccus Diog. Laert. 16.144; Cen. $D N$ 3.2.

6 On this see R. Laurendi, Leges Regiae e Ius Papirianum. Tradizione e storicita' di un ius normativo (Rome: L'Erma di Bretschneider, 2013); S.W. Bell and P.J. du Plessis (eds.), Roman Law before the Twelve Tables: An Interdisciplinary Approach (Edinburgh: Edinburgh University 
However, another important moment should be considered, I argue, as part of this wider search for a coherent codification of the religious and political norms, the writing of the so-called antiquarians, which, composed in the second and first century вС, should be viewed as constituting an intellectual movement of innovative force. ${ }^{7}$ By adopting a philological method, these texts moved from the present to reconstruct the past. Their subject matters concentrated on political institutions and laws, religion, private life and customs, topography, and language. United by a family resemblance in the way they approached the past, they adopted a synchronic rather than chronological arrangement, and appeared prima facie to collect all evidence for a given phenomenon indiscriminately, without an explicit evaluation of its relevance to a particular problem.

In the second half of the second century, authors such as C. Sempronius Tuditanus in his libri magistratuum, L. Cassius Hemina in his de censoribus, I. Congus Gracchanus in his de potestatibus, or in the first century вС Nicostratus in his de senatu habendo, Varro in his Isagogicus ad Pompeum (an instruction manual on how to convene a session of the senate for Pompey), or L. Cincius in his de comitiis, selected customs and institutions, which, enshrined in their works, transformed patterns of customary behaviour into written rules and regulations that governed public life. The contemporary political and institutional uncertainties of the late Republic encouraged and, to a certain extent, drove intellectuals and politicians of the time to elaborate normative models, which, placed in a remote past, gained the auctoritas of the ancestors, while, at the same time, enabling changes for the future. ${ }^{8}$ The process of selection,

Press, 2019); C. Smith, 'Leges Regiae and the Nomothetic World of Early Rome', Cahiers des études anciennes 57 (2020), pp. 91-103. The so-called 'constitutions' of Romulus and Servius in Dionysius of Halicarnassus, the accounts of Cicero's De Republica Book 2, and Livy's narrative in Book 1 can be considered part of this wider intellectual movement. See Gabba, 'Tendenze all'unificazione normativa', pp. 48-9.

7 For a discussion on the nature of Roman antiquarianism see A. Momigliano, 'Ancient history and the antiquarian', Journal of the Warburg and Courtauld Institutes 13 (1950), pp. 285-315 and E. Rawson, Intellectual Life in the late Roman Republic (London: Duckworth, 2002). The works of the antiquarians have not survived in full and their fragments are currently scattered in number of rather outdated editions of Roman jurists, grammarians, and historians - although for the latter we are now much better served by the edition of Tim Cornell, who carefully distinguishes the antiquarian and the historical works. The first edition of the Fragments of the Roman Republican Antiquarians is currently in preparation by a team of scholars led by myself under the egis of the ERC.

8 Gabba, Italia Romana, p. 5o. E. Gabba, 'Studi su Dionigi di Alicarnasso I', Athenaeum 48 (196o), p. 22 ff.; A. Momigliano, Settimo contributo alla storia degli studi classici e del mondo antico (Rome: Edizioni di Storia e letteratura, 1984), p. 430 ff.; A. Wallace-Hadrill, Rome's Cultural Revolution (Cambridge: Cambridge University Press, 2008), pp. 231-7. 
however, was not uncontested, and by asserting one version of the past over another as the most authoritative, each author established and re-defined possible courses of action in the present.

In the second half of the first century $\mathrm{BC}$, an intellectual debate took place on the exact nature and functions of the consulship, traditionally regarded as the highest magistracy in Rome, and its relation with other Republican magistracies and institutions.

The debate focused on two main issues: first, the power relation between the consul and other magistrates, in particular the praetor, as well as the institutions of the senate and the comitia; second, the function fulfilled by the consul in the administration of the res publica.

Livy, writing at the very end of the first century BC, reports a discussion on the law passed, it seems, in 449 BC to protect the tribunes of the plebs. ${ }^{9}$ According to this law, whose main scope was to guarantee the sacrosanctity, that is the personal inviolability, of those magistrates perceived as defenders of the people's interests, those who violated the person of the tribunes of the plebs, of the plebeian aediles and of the decemviral judges, would have been forfeited to Jupiter and their possessions sold at the temple of Ceres, Liber, and Libera. The very lively debate, which Livy retrojects, at least partially, to the fifth century вс, focused on the aim of the law and its scope. ${ }^{10}$ There was, in fact, no consensus on whether the aim of the law was to establish that the magistrates were sacrosanct, or rather, as the iuris interpretes of the first century вС seemed to believe, that the offenders against those officials should have been considered sacer. ${ }^{11}$ Equally, there was no consensus on the magistrates whom this law included in its provisions and whether, alongside the plebeian aediles

$9 \quad$ Liv. 3·55.7-12. See also Zon. 7.19.1 (independent from Livy and also relating to 449).

10 The debate had a strong contemporary relevance as in 36 вс Augustus was granted the sacrosanctity of the tribune, a major move that required some justification. Not a coincidence that Trebatius Testa, Augustus' legal adviser, wrote an essay on the concept of sacer. See R.M. Ogilvie, A Commentary on Livy: Books 1-5 (Oxford: Clarendon Press, 1978), pp. 502-3 and R.A. Bauman, 'Tribunician Sacrosanctity in 44, 36 and 35', Rheinisches Museum für Philologie 124 (1981), pp. 166-83.

11 On sacrosanctity and sacer, Fest. 422, 17-24L; cf. Malcovati $O R F$ (2nd) p. 89, fr. 219. The exact meaning of sacer became a topic of particular controversy in the late second and early first century вС: Fest. 26oL with discussion in E. Tassi Scandone, 'Verberatio parentis e sacer esto. Nuovi elementi di riflessione', Bullettino Dell'Instituto di Diritto Romano 8 (2018), pp. 227-44. 
and the judicial decemviri, the law included the consuls and the praetors in its clauses too. There were some who argued that the law covered a class of officials called iudices, and, as the consuls were called iudices, it followed, they maintained, that the consuls were covered by the law. However, since the praetors were created under the same auspices as the consuls, their argument continued, it could only be deduced that the praetors were included too. The important point of this discussion for my present argument is that those who held this view argued that, since the law covered a group of officials called iudices and the consuls were called iudices, it followed that the consuls were included in the provisions of the law. However, Livy notes that this interpretation should be refuted, as in those (historically unspecified) times it was custom for a judge not to be called 'consul' but rather 'praetor'.

At the kernel of this debate lies the important issue whether the titles 'consuls' and 'praetors' indicated two different functions assigned to the same individual or rather two distinct magistracies with their own individual remits and a hierarchical internal relation. In his de consulum potestate, L. Cincius, an antiquarian who lived in the second half of the first century BC, attests of a time when the two magistracies were distinct and the praetor was indeed the chief military and political authority. ${ }^{12}$ In a very obscure passage preserved by Festus, Cincius discusses the salutatio ad portam, the Roman custom to hail at the gate as praetor the general who was going to take charge of a province either as propraetor or proconsul (Festus 276L). In Pierre Sánchez's recent reading, Cincius states that the origin of this custom lies in the fact that, when Rome fought alongside the Latins under the foedus Cassianum, the command of the allied armies was entrusted to a magistrate of the Roman Republic. Before leaving Rome, the general took the auspices on the Capitol in order to obtain divine confirmation of his military powers, which had been conferred upon him by the people, and was greeted by the Latin armies at the gate of the city with the title of praetor. ${ }^{13}$ The fundamental point of interest for Cincius consists

12 G. Wissowa, 'L. Cincius', $R E$, vol. 3 (Stuttgart, 1899), coll. 2555 ff. On the distinction between L. Cincius and Lucius Cincius Alimentus, see T. Cornell (ed.), The Fragments of the Roman Historians (Oxford: Oxford University Press, 2013), vol. 1, pp. 179-83 onwards for passages that could be attributed to the antiquarian. The first to establish the distinction was M.J. Hertz, De Luciis Cinciis (Berlin: E.H. Schroeder, 1842).

13 For a recent discussion see P. Sánchez, 'Le fragment de L. Cincius (Festus p. 276 L) et le commandement des armées du Latium', Cahiers du Centre Gustave Glotz, 25 (2014), pp. 7-48. A. Ziółkowski, 'The Capitol and the "auspices of departure", in S. Ruciński, K. Balbuza and K. Krolczyk (eds.), Studia Mrozewicz ab amicis et discipulis dedicata (Poznań: Instytut Historii UAM, 2011), pp. 465-71 considers the transmitted text interpolated with no reference to the auspicia of departure. 
in the fact that in the past the praetorship was the chief office in Rome. ${ }^{14}$ The superiority of this magistracy over the consulship was also shown in an archaic inscription that attested a use, which too had attracted the attention of L. Cincius. This inscription, placed on the right side of the temple of Jupiter Optimus Maximus, where the temple of Minerva stands, attested, according to Livy, an ancient law (lex vetusta) that prescribed that, on the Ides of September, the praetor maximus performed the annual ritual of hammering in a nail..$^{15}$ Cincius, described by Livy as diligens talium monumentorum auctor, claimed that this use, adopted to mark the passage of years, was also implemented at Volsinii, where nails could still be seen in the first century вс hammered in the temple of Nortia, an Etruscan goddess. By a direct observation of monuments and inscriptions, Cincius and other authors (Livy generically refers to a plural) attest of a time when writing was not widespread and the chief magistrate in Rome was called praetor maximus. ${ }^{16} \mathrm{He}$ must have been replaced by the consul, or so Livy implicitly claims, as, in the year after the expulsion of the kings, the ceremony of driving the nail was then carried out by the consul Marcus Horatius, and then transferred from consuls to dictators, because theirs was, Livy comments, the higher authority. ${ }^{17}$

14 A. Momigliano, 'Praetor maximus e questioni affini', in A. Momigliano (ed.), Roma arcaica (Florence: Sansoni, 1989), pp. 171-81 = A. Momigliano, Quarto conributo alla storia degli studi classici e del mondo antico (Rome: Edizione di storia e letteratura, 1969), pp. 4O3-17. T.J. Cornell, 'The value of the literary tradition concerning Archaic Rome', in K.A. Raaflaub (ed.), Social Struggles in Archaic Rome: New Perspectives on the Conflict of the Orders (Berkeley: University of California Press, 1986), pp. 52-76; and full discussion in T.J. Cornell, The Beginnings of Rome. Italy and Rome from the Bronze Age to the Punic Wars (c. 1000-264 BC) (New York: Routledge, 1995), pp. 227-30. Cf. Fest. 249.16L: praetoria porta in castris appellatur, qua exercitus in proelio educitur, quia initio praetores erant, qui nunc consules, et hi bella administrabant ... where it is explicitly said that the commanders of the army were called praetores before they were called consuls. See also Varro Ling. Lat. 5.80 and discussion below.

15 Liv. 7.3.5. Cf. Paul. Fest. 49L. J. Heurgon, 'L. Cincius et la loi du cluus annalis', Athenaeum 42 (1964), pp. 432-7 postulates that this must be a reference to Cincius' mystagogion, most likely a guidebook to Rome, where he also deals with an inscription from the Capitol.

16 For a full discussion of this passage see S.P. Oakley, A Commentary of Livy: Books VI-X. Vol. 2, Books VII-VIII (Oxford: Clarendon Press, 1998), ad loc. For its apotropaic function see T.C. Brennan, The Praetorship in the Roman Republic, vol. 1 (Oxford: Oxford University Press, 200o), p. $21 \mathrm{ff}$. See also A. Lintott, The Constitution of the Roman Republic (Oxford: Oxford University Press, 1999), p. 104; Cornell, The Beginnings of Rome, pp. 227-32 who presents an excellent review of all proposed readings. See also L. Caes. Iur. Anteh. 107.2 on praetor maior and praetor minor.

17 Liv. 7.3.8. On the historical development of this ritual see Oakley, A Commentary on Livy, vol. 2, pp. 75-6. A. Momigliano, 'Ricerche sulle magstrature romane', Bolletino della 
Cincius and the other authors to whom Livy refers were only some of the protagonists of this debate that took place in the second half of the first century BC. According to them, in Rome's ancient past the praetor and the consul were distinct magistrates - an idea, Livy comments, also based on the mistaken attribution of the name 'judge' to consuls rather than praetors. However, Cicero in his de legibus, composed too in the second half of the first century BC (approximately between $5^{2}$ and $43 \mathrm{BC}$ ), claimed that these magistracies indicated distinct functions fulfilled by the same individual, who thereby received the name of praetor, judge, and consul. In the legal code for his res publica, Cicero gives the following law: 'there shall be two magistrates with royal powers. Since they lead, judge, and confer, from these functions they shall be called praetors, judges, and consuls (regio imperio duo sunto, iique praeeundo, iudicando, consulendo praetores, iudices, consules appellamino). In the field they shall hold the supreme military power; they shall be subject to no one; the safety of the people shall be their highest law' (Cic. Leg. 3.8.2.).

In one of the rare passages of de legibus where he makes use of an etymological argument, Cicero supports the archaic equivalence between praetors and consuls, as these names show different functions of the same magistrates. These were called praetors, he explains, from prae-ire, to go first, to lead (the army), iudices, from iudicare, to pass judgment, and consuls from consulere, to advise or consult. Proposing the ideal law-code for his res publica, in line with Greek political theory and in accord with the historical reality of early Rome as he reconstructed in de re publica, Cicero adopts an archaising framework, which enables him to present innovations within a wider context aimed at reestablishing, or so he claims, the traditional Roman past. ${ }^{18}$

Cicero's position in the debate of the nature of Republican magistracies was far from isolated. His etymological argument that postulates (or shows, as the ancients would have said) the existence of a time when praetors and consuls were two functions of the same magistracy returns about ten years later in Varro's de vita populi Romani, composed in 43/2 Bс..$^{19}$ In this work, Varro states that 'the terms consuls and praetors indicated the same magistrates: as praetors led the people and as consuls gave advice to the senate (quod idem

Commissione Archeologica Comunale in Rome 58 (1930), pp. 29-55 = Momigliano, Quarto Contributo, pp. 273-327.

18 Cic. Rep. 2.56. On the nature of Cicero's laws in de legbius see J.G.F. Powell, 'Were Cicero's laws the Laws of Cicero's Republic?', Bulletin of the Institute of Classical Studies 45 (2001), pp. 17-39. On iudex as an old designation of the consuls see the formula adopted to summon the citizen army attested in Varro Ling. Lat. 6.88.

19 On the date of composition see A. Pittá, M. Terezio Varrone, de vita populi Romani. Introduzione e commento (Pisa: Pisa University Press, 2015), pp. 7-8. 
dicebantur consules et praetores; quod praeirent populo, praetores; quod consulerent senatui, consules).' ${ }^{20}$ Albeit in the context of a fragmentary text, the only difference between Cicero's and Varro's etymology of consul consists, rather interestingly, in the explicit reference to the receiver of the consuls' advice. In the case of Cicero, as indicated by the reference to the safety of the people as the main political remit of the consuls, in the commonwealth the consuls were expected to give advice and take care of the people. In the case of Varro, in the de vita populi Romani, the consuls were presumed, in a remote past, to give advice to the senate. The two readings of course may well not be mutually exclusive, especially so in the case of the fragmentary work of Varro, but it might be interesting to observe that the absence of the senate in Cicero's formulation is counterbalanced by the absence of the people in Varro's.

This observation gains a new dimension when we consider that just few years earlier, in his de lingua Latina, Varro had also dealt with the etymology of Roman magistrates. ${ }^{21}$ In this work, Varro took a different stance from the one he assumed a few years later in de vita populi Romani. In de lingua Latina, reviewing the etymology of the Roman Republican magistracies, the praetor and the consul are considered two distinct magistrates with separate functions: the praetor is associated with praeire and the consul with consulere. In the first case, Varro states that this magistrate derives his name from the fact that he leads the law and the army (praetor dictus qui praeiret iure et exercitu) an etymology rather uncontroversial in antiquity. ${ }^{22}$ In the latter, Varro presents

$20 \quad$ Varro, Vita p. R. fr. 67 Pittá = Non. P. 23M. I follow Pittá, who in turns follows Lindsay, in preserving the lectio of the codices senatui, contra the emendation senatum by Popma and others: for discussion see Pittá, M. Terenzio Varrone, pp. 7-8. See also J.-C. Richard, 'Praetor collega consulis est: contribution à l'histoire de la préture', Revue de Philologie 56 (1982), pp. 19-31.

21 J.Zetzel, Critics, Compilers, and Commentators: A Guide to Roman Textual and Grammatical Scholarship (New York: Oxford University Press, 2018), p. 34 places the dates of composition between 45 and 43 BC. W. de Melo, Varro, De lingua Latina: Introduction, Text, Translation and Commentary (Oxford: Oxford University Press, 2019), pp. 14-5 reviews the main literature on the topic and comes to a not dissimilar conclusion, placing the composition date between $47-43$ в .

22 Varro Ling. Lat. 5.80 Varro reiterates the same (rather uncontroversial) point at 5.87: in re militari praetor dictus qui praeiret exercitui. The only exception is Isidore, who derives praetor from praeceptor 'teacher' (Orig. 9.4.16: praeceptores civitatis et princepes). Cf. Isid. Orig. 9.3.27: from praepositor 'placer in front'. For a full review of the ancient etymologies of praetor see R. Maltby, A Lexicon of Ancient Latin Etymologies (Leeds: Cairns, 1991), s.v. praetor. C. Gioffredi, 'Ius, lex, praetor', Studia et Documenta Historiae et Juris, 13-4 (19471948), pp. 7-140 argues in favour of an understanding of praetor as the official who leads in reciting a formula in the civil procedures of the legis actiones. Contra Brennan, The Praetorship in the Roman Republic, p. 20. 
two alternatives: the name of this magistrate, he states, may derive from consulere as the consul is the one who should consulere, 'ask the advice of' the people and the senate (consul nominatus qui consuleret populum et senatum). Alternatively, Varro continues, if one follows the use of Accius in his Brutus, the name consul derives from consulere as in 'to give advice', so that the person who counsels right is called consul. ${ }^{23}$

If the derivation of the word consul from consulere is universally accepted in antiquity, Varro shows that there was a significant disagreement about its usage and thereby its meaning. ${ }^{24}$ According to the reading favoured by Varro in de lingua Latina, and, on the basis of our evidence, not widely shared by others, the word consul derives from consulere as understood when governing the accusative, 'asking for advice'. In this case, the consul is the magistrate who consults the senate and the people. In the second case, supported by Accius and fully illustrated by Varro himself in the de vita populi Romani, consulere stands for 'giving advice', 'taking care of', and is usually followed by the dative. ${ }^{25}$

What might appear prima facie a rather tedious discussion of antiquarian nature on the etymology of consul and praetor and their mutual relation was, in fact, an important debate on the constitutional arrangements of the Republic, a debate that was intellectually fought also through the means of etymological research. The kernel of the issue resided in two main points: first, in understanding the power relation between the consul and the praetor, second, and perhaps more pressingly, in establishing the role of the consul in relation to the other two institutional loci of power, the senate and the popular assemblies. This etymological research presented not only a case for the identity of the praetor and the consul, but also, reading Roman institutional arrangements within the framework of Greek political thought, for two conflicting interpretations of the power relation between the three main components of Roman political life, the magistrates, the senate, and the people. In one case, endorsed by Varro in de lingua Latina, in the remote past, the role of the consul was that of consulere senatum et populum, that is asking for the advice of the senate and the people; in the other, proposed by Accius in the Brutus, and endorsed by Cicero and Varro in the de vita populi Romani, the function of the consul was consulere senatui (or, in other attestations, rei publicae or civibus), that is giving

23 Varro Ling. Lat. 5.8o: let the person who counsel right, be called consul (qui recte consulat, consul cluat).

24 For a full review of ancient etymologies of consul see Maltby, A Lexicon of Ancient Latin Etymologies, s.v. consul.

25 See Thesaurus Linguae Latinae s.v. consulo and commentary in de Melo, Varro, De lingua Latina, ad loc. 
advice and taking care of the interests of the senate and the people. ${ }^{26}$ These different etymological interpretations placed the highest magistrates in Rome in distinct power relations with the other institutional loci of the Republic, relations that, in the second half of the first century $\mathrm{BC}$, were strained by the uses and abuses of the consulship by Julius Caesar and to which, I would argue, Varro's etymological innovation of the de lingua Latina might have been responding. ${ }^{27}$

Most interestingly, the role of the consul within the Republican political system was no longer only articulated in public debates, but was now recorded for the first time in the writing of the so-called antiquarians. ${ }^{28}$ The most striking feature of this intellectual battle is that it was fought through the means of etymological research. Contrary to modern phonology and the study of Indo-European derivations, ancient etymologies, as Ineke Sluiter puts it, 'are mostly put forward to corroborate a specific view of what a word "really" means, probably even where they are presented as a tool to find the meaning of a word'. ${ }^{29}$ It follows that ancient etymology are 'all about synchrony, even though it invokes a discourse that references the past. It is about the relationship between words and their semantic explanation or definition - it wants to know why anything is called what it is called, the reason for the name, and what motivates the namegiver - and the explanations it comes up with are not intended to give us insight into the past, into the historical processes and developments leading to the present situation; rather, and importantly,

26 In this context consulere with dative Cic. De Or. 2.165: si consul est qui consulit patriae; Pis. 23: Animo consulem esse oportet, consilio, fide, gravitate, vigilantia, cura, toto denique munere consulatus omni officio tuendo, maximeque, id quod vis nominis ipsa praescribit, rei publicae consulendo; Flor. Epit. 1.9.2: consules ... ut consulere civibus suis debere meminissent; Pomp. Dig. 1.2.2.16: dicti sunt ab eo, quod plurimum rei publicae consulerent. See also Isid. Orig. 9.3.6: consules appelati sunt vel a consulendo civibus vel a regendo cuncta consilio. Consulere with acc. Liv. 22.1.14: consul de religione patres consuluit. See discussion in M. Salvadore, M. Terenti Varronis de vita populi Romani (Hildesheim, Zunich and New York: Olms, 2004), pp. 96-7.

27 In addition to $59 \mathrm{BC}$, Caesar was consul in 48 and consecutively from 46 to $44 \mathrm{BC}$, the year of his assassination, when his colleague Mark Anthony tried to maintain his line. On Caesar's consulships see T.R.S. Broughton, The Magistrates of the Roman Republic (New York: American Philological Association, 1952), vol. 2, under the years 49-44 BC, especially pp. $284-5$ n. 1, and see also vol. 3 pp. 106-8.

28 C. Moatti, La raison de Rome: naissance de l'esprit critique à la fin de la République $\left(I \mathrm{I}^{\mathrm{e}}-\mathrm{I}^{\mathrm{e}}\right.$ siècle avant Jésus-Christ) (Paris: Seuil, 1997), pp. 103-4.

29 I. Sluiter, 'Ancient Etymology: A Tool for Thinking', in F. Montanari, S. Matthaios and A. Rengakos (eds.), Brill's Companion to Ancient Greek Scholarship (Leiden and Boston: Brill, 2015), vol. 2, p. 897 . 
(ancient) etymology is about understanding the present'. ${ }^{30}$ As the case of consul shows, from these etymologies of consul and praetor we do not learn much about, or at least not primarily about, the early magistracies of Rome, but rather how they were perceived at the time of writing. As a form of 'anchoring' practice in the past, which provides orientation in the present, these different etymologies corresponded to different views of the role of the consuls in the contemporary constitutional framework of Rome.

\section{$3 \quad$ Varro's Etymology and Early Kings as Lawgivers}

Etymological reflections are also philosophical reflections. ${ }^{31}$ When set within the appropriate philosophical context, it is possible to see how those who first gave names to institutions and magistrates could be interpreted as de facto law-givers. The etymologist who was able to reach the same level of knowledge as that of the first name-givers could, therefore, claim that his view of, in the case under discussion, the consulship had a higher degree of validity than the other competing arguments.

In his de lingua Latina, Varro treats the nature of language as tripartite: the origins of names, their derivations and inflexions, their combination to express a complete thought, in other words it focuses on etymology, inflexional morphology, and syntax. ${ }^{32}$ In the preserved text on etymologies, Varro explains that words are divided into two groups, primigenia, those first imposed upon things, and declinata, those derived from the first words by either declinatio uoluntaria or declinatio naturalis, that is derivation and inflection.

The origins of words are therefore two in number, and no more: imposition (impositio) and inflection (declinatio); the one is as it were the spring (fons), the other the brook (rivus). Men have wished that imposed nouns should be as few as possible, that they might be able to learn them more quickly; but derivative nouns they have wished to be as numerous

\footnotetext{
30 Sluiter, 'Ancient Etymology', p. 898.

31 On the relation between philosophy and antiquarianism, whose central tool is etymology see P. van Nuffelen, 'Varro's divine antiquities. Roman religion as an image of truth', Classical Philology 105 (2010), pp. 162-88.

32 Varro Ling. Lat. 8.1. D. Blank, 'Varro and the epistemological status of etymology', Histoire Épistémologie Language 30 (2008), p. 54 and for the structure of the work D. Blank, 'Varro's Anti-Analogist', in D. Frede (ed.), Language and Learning. Philosophy of Language in the Hellenistic Age (Cambridge: Cambridge University Press, 2005), pp. 212-4.
} 
as possible, that all might the more easily say those nouns which they needed to use.

VARRO Ling. Lat. 8.5

At the fons, the origin, the men who first imposed names upon things were guided, Varro tells us, by the natura of the things named: 'for nature was man's guide to the imposition of names (de natura eorum: ea enim dux fuit ad vocabula imponenda homini [Varro Ling. Lat. 6.3.]).' Since in de lingua Latina Varro explicitly refers to the Stoics, naming explicitly Chrysippus and Antipater, it is not implausible to imagine with David Blank that Varro embraces their thought that the first name-givers imitated in sound what they found essential about the nature of the thing that they wished to name following an onomatopoietic model or the mode of its articulation. ${ }^{33}$

However, these men decided that these first words should be few in number and their act of name-giving was to be complemented by the process of declination, both voluntaria and naturalis. As Varro puts it,

there are two kinds of derivation, voluntary and natural. Voluntary derivation is that which is the product of the individual person's volition, directing itself apart from control by others. So, when three men have bought a slave apiece at Ephesus, sometimes one derives his slave's name from that of the seller Artemidorus and calls him Artemas; another names his slave Ion, from Ionia the district, because he has bought him there; the third calls his slave Ephesius, because he has bought him at Ephesus. In this way each derives the name from a different source, as he preferred. On the other hand, I call that derivation natural, which is based not on the volition of individuals acting singly, but on general agreement. So, when the names have been fixed, they derive the case-forms of them in like fashion, and in one and the same way they all say in the genitive case Artemidori, Ionis, Ephesi; and so on in the other cases.

VARRO Ling. Lat., 8.21-2

33 Blank, 'Varro and the epistemological status of etymology', p. 56. On Stoic etymologies see J. Allen, 'The Stoics on the origin of language and the foundations of etymology', in D. Frede and D. Inwood (eds.), Language and Learning. Philosophy of Language in the Hellenistic Age (Cambridge: Cambridge University Press, 2005), pp. 14-35; A. Verlinsky, 'Posidonius' Linguistic Naturalism and Its Philosophical Pedigree', in G. Pezzi and B. Taylor (eds.), Language and Nature in the Classical Roman World (Cambridge: Cambridge University Press, 2019), pp. 15-45; A. Garcea, 'Nigidius Figulus' Naturalism', in Language and Nature in the Classical Roman World, pp. 79-102; and D. Blank, 'What's Hecuba to Him? Varro on the Natural Kinship of Things and of Words', in Language and Nature in the Classical Roman World, pp. 121-52. 
The prime function that, according to this thinking, the natural declination fulfils is to enable men to learn as quickly as possible an enormous amount of words. After the first act of impositio, when the name-givers imposed few original names, by virtue of derivation and inflection, an infinite number of things could be named (Varro Ling. Lat. 8.3). According to Cosconius, Varro reports, the primitive words were about one thousand, 'from the inflections of these words the different forms can be five hundred thousand in number for the reason that from each and every primitive word about five hundred forms are made by derivation and inflection' (Varro Ling. Lat. 6.36). Thus, from the original fons, a rivus of words came to be formed. However, searching for 'from what thing and to what thing' a name is imposed, Varro finds his quest hampered by numerous obstacles: first, not every imposed name survives since the passage of time has destroyed some of them; second, not every imposed name which survives does so without inaccuracy of some kind; third, not every correct imposed name remains unaltered, as many have their letters changed, while, fourth, others have kept the same forms, but changed their meaning, and, finally, others derive from a foreign language (Varro Ling. Lat. 5.2-3).

'These words [of origin, the first imposed]', Varro tells us, 'are covered up ... by lapse of time, [and] I shall try to dig [them] out as best I can (quae obruta vetustate ut potero eruere conabor). ${ }^{34}$ However, as the fons, the originating source, of the words primigenia is about seven hundred years old, as attested, for example, by the words of the carmen Saliorum, it is unreasonable to expect that anyone who studies these issues may always succeed in identifying the causa of the words (Varro Ling. Lat. 7.3). Therefore, he claims, since the origin of all words (causa omnium verborum) cannot invariably be stated, one should not blame the person who has been unable to reach it, but rather appreciate that many interesting and important things can still be learnt by the etymological research.

Just as it cannot be stated how and why a medicine is effective for curing; and that if I have no knowledge of the roots of a tree, still I am not prevented from saying that a pear is from a branch, the branch from a tree, and the tree from roots which I do not see. For this reason, he who shows that equitatus 'cavalry' is from equites 'cavalrymen', equites from eques 'cavalryman', and eques from equus 'horse', even though he does not

34 Varro Ling. Lat. 6.2. On Varro's metaphor of archaeology see V. Binder, 'Inspired Leaders versus Emerging Nations: Varro's and Cicero's Views on Early Rome', in K. Sandberg and C. Smith (eds.), Omnium Annalium Monumenta: Historical Writing and Historical Evidence in Republican Rome, vol. 2 (Leiden and Boston: Brill, 2018), pp. 157-81. 
give the source of the word equus, still gives several lessons and satisfies an appreciative person.

VARRO Ling. Lat. 7.4

Thus, according to Varro, the inability to state the ultimate origin of a word should not be considered a failure, since, by unearthing how the other nouns have developed from the primitives, the author has undoubtedly shed some significant light on a variety of important issues. By highlighting the transitional relation between the words equitatus and equus, to take Varro's own example, but ceasing his search once the latter is reached, Varro thinks something important has been uncovered about the Roman institution of cavalry, which would not necessarily be further enriched by a full understanding of the origin of equus. However, Varro's aim remains to establish the words primigenia, that is words like lego 'I gather', scribo 'I write', sto 'I stand', sedeo 'I sit', 'and the rest which are not from some other word, but have their own roots'. The main reason for this quest, it seems, is of a pragmatic nature: by discovering the origines of approximately one thousand primitive words, he would reveal the sources of five hundred thousand new words. However,

if without showing the origin of a single primitive word he has shown how the rest have developed from the primitives, he will have said quite enough about the origins of words, since the original elements from which the words are sprung are few and the words which have sprung from them are countless.

VARRO Ling. Lat. 6.37

To achieve this very ambitious aim, that is to reach the causa of the primitive words first imposed on things, Varro states that he will need to resort not to the ars of etymology and its rules on how to inflect words, which will not bear any fruits in this context, but rather to historia.

In connexion with the first class [the impositicia verba] historia is necessary, for except by outright learning such words do not reach us (ad illud genus, quod prius, historia opus est: nisi discendo enim aliter id non pervenit ad nos); for the other class, the second [declinata verba], a grammatical treatment is necessary, and for this there is need of a few brief maxims. For the scheme by which you have learned to inflect in the instance of one noun, you can employ in a countless number of nouns.

VARRO Ling. Lat. 8.6 
Thus, according to Varro, it is possible to reach the origins of the impositicia verba by historia and erudite learning, that is by research of each particular coinage, its context, and its reasons. ${ }^{35}$ This will be the highest level of the investigation of the word origins, which Varro calls the fourth gradus, where, he says, the adytum et initia regis are located: ${ }^{36}$

The fourth level is where the sanctuary and the mysteries of the highpriest are. If I do not arrive at full knowledge there, at any rate I shall hunt after an informed opinion, which even in matters of our health the physician does from time to time when we are ill. ${ }^{37}$

VARRO Ling. Lat. 5.8

However, he wishes to reach the highest level that he possibly can:

But even if I do not reach the highest level, I shall nevertheless surpass the second, because I spent my nights studying not only by the lamp of Aristophanes, but also that of Cleanthes. I wanted to surpass those who explain only how the words of the poets were created. For it did not seem appropriate that I should seek the source in the word which Ennius had

35 Blank, 'Varro and the epistemological status of etymology', p. 66. G. Piras, Varrone e $i$ poetica verba: studio sul settimo libro del De lingua latina (Bologna: Pàtron, 1998), pp. 62-3 who underlines the role of historical research in ancient grammar. See also Blank, 'What's Hecuba to Him?', p. 148, and J. Zetzel, 'Natural Law and Natural Language in the First Century BC', in Language and Nature in the Classical Roman World (Cambridge: Cambridge University Press, 2019), pp. 191-211.

36 For this reading see also J. Collart, Varron: grammaire antique et stylistique latine pour Jean Collart (Paris: Les Belles Lettres, 1978), p. 275, who, however, emphasises its Pythagorean knowledge.

37 Quartus, ubi est adytum et initia regis. Quo si non perueniam $\langle a d\rangle$ scientiam, at opinionem aucupabor, quod etiam in salute nostra nonnunquam facit cum $\langle a\rangle$ egrotamus medicus. The text is notoriously corrupt. Here I adopt the text and the translation by W. de Melo (ed.), Varro, De lingua Latina: Introduction, Text, Translation and Commentary (Oxford: Oxford University Press, 2019), ad loc. For discussion and emendations of the corrupt text, see R. Schröter, Varron (Geneva: Entretiens Foundation Hardt IX, 1963), esp. pp. 101-16 and de Melo, Varro, De lingua Latina. Most recently see F. Lazzerini, 'Romulus' adytum or asylum? A New Exegetical Proposal for De lingua Latina 5, 8', Ciceronia OnLine 1 (2017), pp. 97-128: asylum for adytum. On the interpretation of this passage much has been written: alongside those already cited, see W. Pfaffel, Quartus gradus etymologiae. Untersuchungen zur Etymologiae Varros in De lingua Latina (Königstein and Taunus: Hain, 1981), pp. 231-44 and Piras, Varrone e i poetica verba, pp. 57-71. For initia as reference to the mysteric initiations see R. Schröter, Studien zur varronischen Etymologie (Mainz: Akad. D. Wiss. U. d. Lit., 196o), p. 89 ff.; Piras, Varrone e i poetica verba, pp. 65-6 and van Nuffelen, 'Varro's divine antiquities', p. 180 ff. 
created and should neglect what King Latinus had created before, given that I get more enjoyment than utility from many poetic words and that I get more utility than enjoyment from the ancient ones. Are not those words mine which have come to me from King Romulus by inheritance, rather than those which have been left behind by the poet Livius?

VARRO Ling. Lat. $5 \cdot 9$

It seems, therefore, that, according to Varro, the first name-givers were the early kings of Rome, who understood the nature of the thing to which they imposed the name of the origins..$^{38}$ Guided by the natura of things, these extraordinary men, such as Latinus, Romulus, or Numa, whom Varro cites as the name-giver of religious institutions (Varro Ling. Lat. 7.3; 7.45), applied their ratio, their rational observation, to the reading of the world around them to which theygavenames. ${ }^{39}$ 'The useful service for which names were set upon things', Varro argues, 'is that names should signify those things' (Varro Ling. Lat. 8.27)..$^{40}$ It is the natura of the things of the world that first informed language, ${ }^{41}$ which, in turn, makes the knowledge of the world possible (Varro Ling. Lat. 6.60). This is the reason why, although the words invented by the poets give Varro more pleasure, those created by the early kings of Rome are more useful, as they capture the essence of the things. These early kings, the impositores nominis, who crafted the names also of the first Roman institutions being guided by their natura, were therefore the first Roman law-givers. ${ }^{42}$

As long noted by scholarship, here Varro takes a philosophical stance that closely resembles that of Cratylus in Plato's homonymous dialogue. ${ }^{43}$ In Plato,

38 Schröter, Studien zur varronischen Etymologie, p. 93 and P. Boyancé 'Etymologie et théologie chez Varron', Revue des études latines 53 (1975), p. 108 show that the identification of these reges with the rex sacrorum is not tenable.

39 Contra de Melo, Varro, De lingua Latina who considers natura in Varro's etymological books as meaning the outside world. Zetzel, 'Natural Law and Natural Language', who does not see any specific meaning to be attributed to natura.

40 Cf. Varro Ling. Lat. $5 \cdot 3$ where, as Blank notes ('Varro and the epistemological status of etymology', p. 61 n. 46), ostendere and significare are made equivalent.

41 Blank, 'Varro and the epistemological status of etymology', pp. 63-4. For an understanding of the name-giving within the framework of the Stoic oikeiosis, see Blank, 'What's Hecuba to Him?', pp. 121-52.

42 On the role of the king as onomatoteta or impositor nominis see A. Michel, 'Le philosophe, le roi et le poète dans le De lingua Latina', Revue de philologie, de literature et d'histoire anciennes 39 (1965), p. 69 ff. who emphasises the Pythagorean origin of the tradition expressed in Plato's Cratylus.

43 On the equivalence between onomoteta and nometeta in Varro see Michel, 'Le philosophe, le roi et le poète', p. 70 and Boyancé 'Etymologie et théologie', pp. 99-115. 
the name-givers 'keep in view the name which belongs by nature to each particular thing and are able to embody its form in the letters and syllables' (Plato Cra. 39oe). ${ }^{44}$ These are the 'first names', that is the elementary names, which indicate 'what each of the beings is like' by means of letters and syllables so that they imitate the essence of the thing to which they refer (Plato Cra. 421c-424a). However, as Plato makes Socrates comment, Cratylus is right in saying that not everyone possesses the art of crafting names, but only those who can see the essence of things and imitate it in the first names are able to do so. And the one who gives the first names, Cratylus argues, is a nomothetes. ${ }^{45}$ The main function of imposing the first names, according to Cratylus, is to show what the thing named is like and, therefore, it follows that names are given with the aim of teaching (Plato Cra. 428d-429b). The argument is then reformulated later, when Cratylus states that the function of names is to instruct: knowing names, that is knowing their etymology, is the only way of knowing the things named. ${ }^{46}$

Varro's understanding of etymological research was not only in line with Plato, but importantly, was so perceived by his contemporaries. In Cicero's Academica, describing what he presents as Platonic philosophy, the character Varro, whom Cicero says he had cast as Antiochus' spokesperson, presents etymology as a tool by which reason can learn the truth. ${ }^{47}$

Knowledge, on the other hand, they deemed to exist nowhere except in the notions and reasonings of the mind; and consequently they approved the method of defining things, and applied this 'real definition' to all the subjects that they discussed. They also gave approval to derivation of words, that is, the statement of the reason why each class of things bears the name that it does - the subject termed by them etymology and then they used derivations as 'tokens' or so to say marks of things, as guides for arriving at proofs or conclusions as to anything of which they desired an explanation.

Cic. Acad. $1.3^{2}$

44 See F. Ademollo, The Cratylus of Plato: A Commentary (Cambridge: Cambridge University Press, 2018), pp. 95-145.

45 Plato Cra. 388b, 429a, 431e, 436bc.

46 Plato Cra. $435 \mathrm{~d}-436$ a. See also discussion in Ademollo, The Cratylus of Plato, pp. 383-448.

47 Cic. Ad Fam. 9.8.1: 'I have cast you for the part of champion of Antiochus, whose doctrine I think I have understood you to approve of (tibi dedipartes Antiochinas, quas a te probari intellexisse mihi videbar).' On Antiochus and Varro see D. Blank, 'Varro and Antiochus', in D. Sedley (ed.), The Philosophy of Antiochus (Cambridge: Cambridge University Press, 2012), pp. 250-89. 
It may well be that Varro derives this understanding from his teacher Antiochus of Ascalon, as seems most probable, or perhaps from the Stoics, or even Plato himself. ${ }^{48}$ The crucial point for the present argument, however, is that this understanding of etymology as a means to access the truth of the things, which Cicero's Varro traces back to Plato, lies at the core of the role of the early kings as impositores nominis.

However, one might object, as Socrates does in the Cratylus, if our true understanding of the world is dependent on the understanding of their names, it follows that our knowledge is ultimately dependent on the understanding of the legislator who first gave things their names. ${ }^{49}$ However, according to Varro, these early kings of Rome were men of such exceptional gifts and talent that they deserved divine honours and, eventually, divine status. It was only possible for men of divine nature to be able to see the truth, as, according to Varro (whose thought Augustine purports to report), it belongs to man to have opinion, to god to have knowledge. 50

48 See Michel, 'Le philosophe, le roi et le poète'; from Antiochus also Boyancé 'Etymologie et théologie', p. 109; Blank, 'Varro and the epistemological status of etymology'; van Nuffelen, 'Varro's Divine antiquities'; Y. Lehmann, Varron: Théologien et philosophe romain (Brussels: Latomus, 1997). On the epistemology of Antiochus see C. Brittain, 'Antiochus' Epistemology', in D. Sedley (ed.), The Philosophy of Antiochus (Cambridge: Cambridge University Press, 2012), pp. 104-30. Varro claimed to have studied under the lamp of Aristophanes, who had arranged the Platonic dialogues in trilogies, see Diog. Laert. 3.61-2. However, Varro Ling Lat. 7.37 may be an indication that he had had access to Plato's works organised in tetralogies, making less probable that he had access to the Platonic corpus arranged by Aristophanes. Cf. Gal. Freedom from grief 13 with reference to the Atticiana and discussion in M. Hatzimichali, 'The texts of Plato and Aristotle in the first century BC', in M. Schofield (ed.), Aristotle, Plato and Pythagoreanism in the First Century BC. New Directions for Philosophy (Cambridge: Cambridge University Press, 2013), pp. 1-27.

49 Plato Crat. 40od-401a; 411bc; 436ab; 439bc: Socrates suggests that names may give access only to the opinions of the name-givers, which may indeed be erroneous.

$50 \quad$ Aug. Civ. Dei. 7.17 (fr. 228 Cardauns). Cf. Varro, de gente populi Romani fragments $35^{-39}$ Fraccaro; for an interesting historical contextualisation concerning the deification of Caesar see L.R. Taylor, 'Varro's De gente populi Romani', Classical Philology 29 (1934), pp. 221-9. Along the lines of the divine nature of the early kings see also F. della Corte, Varrone: il terzo gran lume romano (Florence: La Nuova Italia, 1970), pp. 110, $113 \mathrm{ff}$. and van Nuffelen, 'Varro's divine antiquities', p. 163. Contra Piras, Varrone e i poetica verba, p. 68 who underlines the human dimension of the early kings. 
'Since ancient etymology', as Sluiter shows, 'is not about the reconstruction of the single, historically accurate, route from word form to word form, but about using language as a tool for thinking about contemporary reality, this intellectual framework does not require just one single and accurate etymology for each word. ${ }^{51}$ Several etymologies of the same word can co-exist, each corresponding to a different view of the underlying reality. When articulated by a prominent politician of the late Republic, these etymologies could also become a powerful tool to ascertain different positions in the debate on the political structure of the commonwealth. By claiming that consul derives from consulere senatum et populum, that is from 'asking the advice of the senate and the people', Varro is making a very important constitutional point. By adopting the framework of Greek political thought, arguably in response to the uses and abuses of the consulship by Caesar and his followers, he affirms the subordination of the consuls to both the senate and the people. This very important statement gains further significance when set within the contemporary intellectual debate on the etymology of Roman magistrates, which was very lively at the time. While all other intellectuals argue for a derivation of consul from consulere senatui (or rei publicae or even civibus), that is 'giving advice to the senate' (or even 'taking care of the interests of the res publica' or 'of the citizens'), and by doing so assert the superiority of the Roman chief magistrate over the advisory power of the senate as well as his role as primary interpreter of the need of the res publica, Varro makes an important intellectual move that inverts this prevalent position, conceivably responding to the inappropriate, in his view, use of the consulship by Caesar. ${ }^{52}$ However, in his eyes, and in eyes of those who shared his philosophical outlook, his stance should prevail as ontologically superior. When set within its proper philosophical framework, in fact, Varro's etymological research confers to his reading a sense of higher

\footnotetext{
51 Sluiter, 'Ancient Etymology', p. 914 ff.

$5^{2}$ The urgency of the Varronian message forged by the contingent historical context ceased to exist, one might argue, in March 44 BC with the assassination of Caesar. Bearing in mind the limitations imposed by the fragmentary state of the text, this might go some way to explain (not without a certain degree of speculation) why Varro returns to the more common view of the etymology of consul in his de vita populi Romani in 43/2 BC. For Varro's political views, see T.P. Wiseman, Remembering the Roman People: essays on late-Republican politics and literature (Oxford: Oxford University Press, 2009), pp. 10751. More recently, see R.M.A. Marshall, 'Varro, Atticus, and the Annales', in V. Arena and F. Mac Góráin (eds.), Varronian Moments, Special Issue of Bulletin of Classical Studies 60.2 (2017), pp. 61-75.
} 
validity. Varro's aim is to reach the fourth gradus of etymology, that of the early kings, the Roman lawgivers, who, through their rational understanding of the natura of things of the world, crafted their first names. By reaching this level, or, if this proves too difficult, the one below - which, however, Varro reminds his readers, provides very useful knowledge - he can achieve (or get as close as possible to achieve) the truth via the dialectical methods of the verborum explicatio. This, in turn, confers his reading of the consulship an absolute value and provides it with a compelling legitimacy, which sets it apart from competing contemporary understandings of the role of this magistracy. Through the study of etymology, an inductive process from the present to the past, Varro could reach the true nature, the essence, of things, human and divine. ${ }^{53}$ It was this nature that was kept in view by the first lawgivers of Rome, whose knowledge was of divine nature.

Although Varro, alongside the other antiquarians, cast these institutions in terms of continuity with the past, this process was by its very nature innovative. Validating responses to the changing needs of society on the basis of his philosophical enquiry, Varro presented himself as the establisher of those rules and regulations which were the foundation of power-sharing of the Republic. It follows that by doing so, Varro contributed directly to the constitutional debates of the late Republic. In his view, informed by his philosophical thinking, the early kings of Rome were the first name-givers and, therefore, the first lawgivers. In a way, Varro's epistemology was another declension of the wider intellectual tendency of the time, which, against Cato's and Polybius' view, reported by Cicero, identified the first kings as the legitimate source of the political and legal structures of the Republic. ${ }^{54}$

By exploring the philosophical dimension that informed his perspective on the origins of language, Varro emerges not as a nostalgic restorer of a lost tradition, although he was undoubtedly interested in establishing a version of that tradition, nor as an antiquarian interested in the study of the Roman past per se, but rather as an intellectual and politician whose philosophical ideas about language underpinned his research and acted as a form of intervention in the contemporary world of politics. ${ }^{55}$ Antiquarian research was, ultimately,

53 G. Piras, 'Dicam dumtax quod est historicon: Varro and/on the past', in Arena and Mac Góráin (eds.), Varronian Moments, pp. 8-20.

54 C.J. Smith, 'Thinking About Kings', Bulletin of the Institute of Classical Studies 54 (2011), pp. 21-42.

55 H.M. Dahlmann, 'Terentius Varro', $R E$, Suppl. 6 (Stuttgart: Metzler 1935), pp. 1172-1277; H.D. Jocelyn, 'Varro's Antiquitates Rerum Diuinarum and Religious Affairs in the late Republic', Bulletin of the John Rylands Library, 65 (1982), pp. 148-205; C. Moatti, 'La crise de la tradition à la fin de la République romaine à travers la littérature juridique et la science 
a philosophical enquiry: Varro's etymological studies were a search for philosophical truth and the language of political institutions, conceived in this perspective, was a weapon in the struggle of the constitutional debates of the late Republic. ${ }^{56}$

des antiquaires', in M. Pani (ed.), Continuità et trasformazioni fra Repubblica e Principato: istituzioni, politica, società (Bari: Edipuglia, 1991), pp. 31-46; E. Romano, 'Il concetto di antico in Varrone', in M. Citroni (ed.), Memoria e identità: la cultura romana costruisce la sua immagine (Florence: Università degli studi di Firenze, 2003), pp. 99-118; I. Leonardis, Varrone, unus scilicet antiquorum hominum: senso del passato e pratica antiquaria (Bari: Edipuglia, 2019). Along interpretative lines consonant to mine, see van Nuffelen, 'Varro's divine antiquities' and, more recently, Binder, 'Inspired Leaders versus Emerging Nations', p. 177: 'Varro was an agent of rationalization, to be sure, but this was not a rationalization separate from politics, nor did it belong in an ivory tower, but it was a deliberate stance in an ongoing struggle about whose past - and whose state - was at stake.'

56 I would like to thank Dimitri El Murr and the other conference participants for the most stimulating discussions and Richard Marshall, Antonino Pittá, and Jessica Clark for important comments on this paper. This research has been conducted under the aegis of the project The Fragments of the Roman Republican Antiquarians (FRRAnt), ERC, consolidator grant86640o. 